\title{
Calcium Current Measurements in Acutely Isolated Neonatal Cardiac Myocytes
}

\author{
GLENN T. WETZEL, FUHUA CHEN, WILLIAM F. FRIEDMAN, AND THOMAS S. KLITZNER
}

Department of Pediatrics, Division of Cardiology, University of California at Los Angeles, Los Angeles, California 90024

\begin{abstract}
Action potentials and voltage clamp-induced ionic currents were recorded in acutely isolated neonatal rabbit cardiac myocytes using the whole-cell voltage clamp technique. Time- and voltage-dependent $\mathrm{Ca}^{2+}$ currents in neonatal myocytes were elicited by depolarizations from a holding potential of $-80 \mathrm{mV}$ to various clamp potentials. The maximal measured inward $\mathrm{Ca}^{2+}$ current was $206 \pm 10$ pA (mean \pm SEM, $n=51)$. The peak current occurred at a mean membrane potential of $7.8 \pm 1.3 \mathrm{mV}(n=51)$. The $\mathrm{Ca}^{2+}$ current voltage relation was shifted $26 \mathrm{mV}$ in the positive direction when the external $\mathrm{Ca}^{2+}$ concentration was increased 10 -fold. $\mathrm{Ca}^{2+}$ current rundown was observed with a half-time of approximately $20 \mathrm{~min}$. Cells dialyzed with solution containing the $\mathrm{Ca}^{2+}$ chelating agent, EGTA $(0.04 \mathrm{mM})$, had action potential durations similar to those previously reported in papillary muscle. In contrast, a higher concentration of EGTA $(14 \mathrm{mM})$ prolonged the action potential duration. Control of the cell internal ionic composition was achieved by dialysis of the cell with a time constant for $\mathrm{Na}^{+}$ions of 1.2 to $2.6 \mathrm{~min}$. Tetrodotoxin $(10 \mu \mathrm{M})$, included in some experiments to block $\mathrm{Ca}^{2+}$ entry via $\mathrm{Na}^{+}$channels, was shown to be more than $98 \%$ effective. These results characterize the whole-cell voltage clamp technique as applied to immature heart cells. (Pediatr Res 30: 83-88, 1991)
\end{abstract}

\section{Abbreviations}

TTX, tetrodotoxin

$I_{\text {peak, }}$, peak current

I-V, current-voltage

$\mathbf{R}_{\mathrm{s}}$, series resistance

$\tau_{\mathrm{Na}}$, time constant for $\mathrm{Na}^{+}$current

$\mathrm{V}_{\text {clamp, }}$, clamp potential

$V_{\text {hold }}$ holding potential

HEPES, $N$-2-hydroxyethylpiperazine- $N^{\prime}$-2-ethanesulfonic acid

Calcium ions play a central role in the generation of action potentials and the development of tension in myocardial cells. Changes in myoplasmic calcium concentration are thought to be mediated by sarcolemmal calcium transport as well as release of $\mathrm{Ca}^{2+}$ from intracellular stores $(1,2)$. The relative contribution of these two processes to tension generation demonstrates both species and developmental variability (3-6). In this regard, age-

Received August 31, 1990; accepted February 28, 1991.

Received August 31,1990 , accepted Februar 28 , Klitzner, M.D., Ph.D., DepartCorrespondence and reprint requests

Supported in part by funding from the NIH (HL-01347 and HL-035783), the American Heart Association, Greater Los Angeles Affiliate (829 GI, 788 IG), and the Variety Club J. H. Nicholson Endowment. T.S.K. is currently a Senio Investigator of the American Heart Association, Greater Los Angeles Affiliate. related changes in cellular ultrastructure (7-9) and the function of the sarcoplasmic reticulum (10-12) have been described Developmental aspects of sarcolemmal $\mathrm{Ca}^{2+}$ channels, however, remain largely unexplored.

The refinement of the whole-cell voltage clamp technique (13) has stimulated significant advances in the study of cellular ionic currents and mechanisms of tension generation (for review see reference 14). Investigators using this technique have directly measured $\mathrm{Ca}^{2+}$ channel characteristics in isolated adult cardiac myocytes (15-17). In contrast, there is little experience with freshly isolated neonatal mammalian myocytes. $\mathrm{Ca}^{2+}$ currents have been recorded in embryonic chick (18), cultured fetal rat (19-21), and neonatal rabbit (22) myocytes. Other investigators have described the action potential configuration in cell aggregates and papillary muscles $(23,24)$.

We report the first measurement of action potential characteristics and time- and voltage-dependent $\mathrm{Ca}^{2+}$ currents in acutely isolated neonatal mammalian myocytes. The methods used in these experiments are similar to those described for studies of $\mathrm{Ca}^{2+}$ channels in acutely isolated adult cardiac myocytes. However, because differences between neonatal and adult myocytes may influence the interpretation of experimental results using this method, a detailed validation of this technique as applied to immature cells is presented. This experimental approach allows for direct comparison of $\mathrm{Ca}^{2+}$ currents between neonatal and adult myocytes using similar methodologies.

\section{MATERIALS AND METHODS}

Cell isolation. Cardiac myocytes were prepared from the hearts of neonatal ( 1 - to 5 -d-old, 50- to 100-g) New Zealand White rabbits by enzymatic dissociation as described previously (25). Animals were anticoagulated with $1000 \mathrm{U}$ of heparin and anesthetized with pentobarbital $(50 \mathrm{mg})$ by intraperitoneal injection. The intact heart was excised rapidly and allowed to beat spontaneously in warmed $\left(37^{\circ} \mathrm{C}\right)$ oxygenated $3.5 \mathrm{mM} \mathrm{Ca}^{2+}$ Tyrode's solution to facilitate removal of blood from the ventricles [solution composition (concentrations expressed in $\mathrm{mM}$ ): $\mathrm{NaCl} 136$, $\mathrm{KCl} 5.4, \mathrm{NaH}_{2} \mathrm{PO}_{4} 0.33, \mathrm{MgCl}_{2}$, HEPES 10, mannitol 4, thiamine $\mathrm{HCl} 0.6$, glucose 10 , pyruvic acid $2, \mathrm{CaCl}_{2}, 3.5 ; \mathrm{pH}$ 7.35 ]. Tyrode's solution was filtered through a $0.45-\mu \mathrm{m}$ plain nylon filter (Micron Separations Inc., Westborough, MA).

The aorta was cannulated and the heart perfused (Minipuls peristaltic pump, Gilson, Middleton, WI) with warmed, oxygenated $0 \mathrm{mM} \mathrm{Ca}{ }^{2+}$ Tyrode's solution at a flow rate of $2.2 \mathrm{~mL} /$ minute for $3 \mathrm{~min}$. The pericardium and atrial appendages were removed. The heart was then perfused with enzyme solution for 7 to 9 min until the heart began to soften. The enzyme solution consisted of $0 \mathrm{mM} \mathrm{Ca}{ }^{2+}$ Tyrode's solution containing collagenase $(1 \mathrm{mg} / \mathrm{mL}=300 \mathrm{U} / \mathrm{mL}$, Type I; Sigma Chemical Co., St. Louis, MO) and protease $(0.07 \mathrm{mg} / \mathrm{mL}=0.35 \mathrm{U} / \mathrm{mL}$, Type XIV; Sigma) that had been filtered through a $0.8-\mu \mathrm{m}$ filter. The perfusate was then changed to $0.1 \mathrm{mM} \mathrm{Ca}{ }^{2+}$ Tyrode's solution for $3 \mathrm{~min}$. The ventricles were removed, opened, and shaken in 0.1 
$\mathrm{mM} \mathrm{Ca}{ }^{2+}$ Tyrode's solution to disperse individual myocytes. The myocytes were then maintained in $0.1 \mathrm{mM} \mathrm{Ca}^{2+}$ Tyrode's solution without further manipulation. The yield of viable myocytes ranged from 30 to $60 \%$.

Viable neonatal cells were spindle-shaped and had recognizable striations and nuclei (Fig. 1). They excluded trypan blue dye and did not contract spontaneously. However, they contracted in response to depolarizing currents (25). Nonviable cells frequently had spontaneous contractions and rapidly lost identifiable intracellular organization. All experiments were performed within 6 $\mathrm{h}$ of cell isolation.

Experimental preparation. Isolated cells were placed in a 1 $\mathrm{mL}$ experimental chamber on the stage of an inverted microscope (Nikon, Garden City, NY). Microelectrodes were prepared from no. 7052 glass capillary tubing (Corning, Horsehead, NY) using a double-pull technique (26). The pipette tip resistance measured 5 to $8 \mathrm{M} \Omega$ in Tyrode's solution. Cells were voltage clamped using an EPC-7 (Adams/List, Great Neck, NY) patch clamp amplifier (13). The current signal was filtered at $1 \mathrm{kHz}$ using an eight-pole Bessel filter (Frequency Devices, Haverhill, MA). Membrane potential and current were recorded on a dual beam storage oscilloscope (Tektronix, Beaverton, OR) and photographed for later analysis. All experiments were performed at room temperature (maintained between 23 and $24^{\circ} \mathrm{C}$ ).

Cell seal resistance was calculated by dividing $V_{\text {hold }}$ by the holding current. Current capacitive transients were minimized by adjusting the transient cancellation circuitry of the patch clamp amplifier. Cell access $R_{s}$ was calculated as the reciprocal of the passive conductance of the preparation (" $G_{\text {series }}$ " on the patch clamp amplifier) (27).

Because the capacitance of biologic membranes is reasonably constant at $1 \mu \mathrm{F} / \mathrm{cm}^{2}$, measurement of the cell capacitance yields an estimate of the cell membrane surface area (26). Cell capacitance was taken as the value of the slow capacitive transient circuit during optimum transient cancellation.

Action potentials were stimulated by brief depolarizations ( 10 $\mathrm{ms}$ ) and recorded with the clamp amplifier in the current clamp mode. The composition of the internal (pipette) solution was in mM: $\mathrm{KCl} 120$, EGTA 14, HEPES 20, $\mathrm{NaH}_{2} \mathrm{PO}_{4} 10, \mathrm{MgCl}_{2} 1$, $\mathrm{CaCl}_{2} 1$, and ATP-Mg 10, titrated to $\mathrm{pH} 7.1$ with KOH. The external bath was Tyrode's solution with $1.8 \mathrm{mM} \mathrm{Ca}^{2+}$.

Measurement of $\mathrm{Ca}^{2+}$ currents. $\mathrm{Ca}^{2+} \mathrm{I}-\mathrm{V}$ relations were determined by employing sequential $100-\mathrm{ms}$ depolarizations $\left(\mathrm{V}_{\text {clamp }}\right.$ $=-40$ to $60 \mathrm{mV}$ ) from a $V_{\text {hold }}$ of $-80 \mathrm{mV}$ at 5-s intervals. $I_{\text {peak }}$

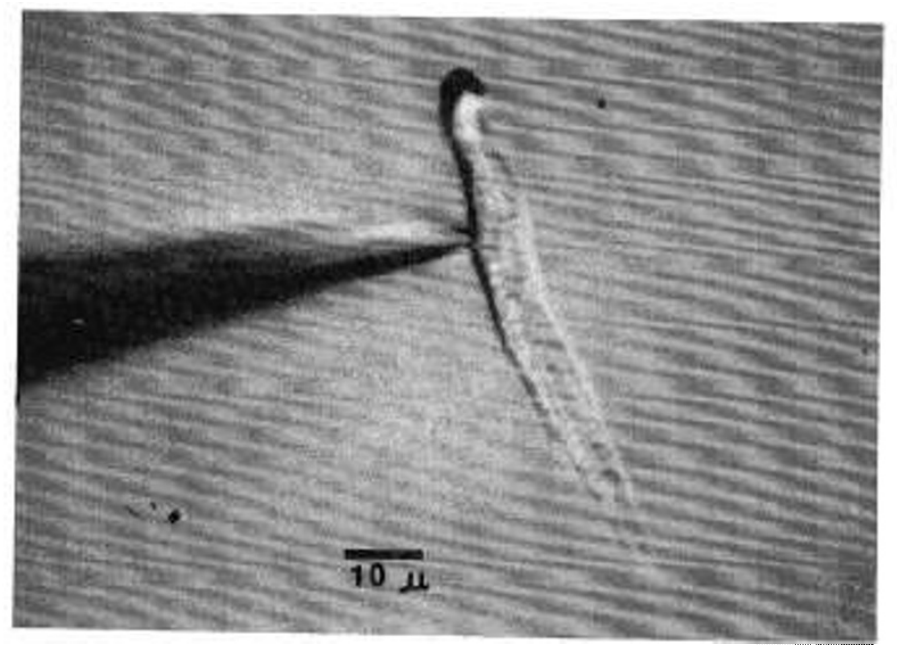

Fig. 1. Photograph of a typical neonatal ventricular myocyte isolated from a 4-d-old rabbit with micropipette in continuity with the cell interior. Note the cylindrical shape, well-defined striations, and intracellular ultrastructure. No vacuoles or other abnormal morphologic features are present. The cell is approximately $70 \mu \mathrm{m}$ long and $7 \mu \mathrm{m}$ wide with a calculated surface area of $16 \times 10^{-6} \mathrm{~cm}^{2}$. was measured for each $\mathrm{V}_{\text {clamp }}$ and net current $\left(\mathrm{I}_{\text {net }}\right)$ calculated as $I_{\text {net }}=I_{\text {peak }}-I_{\text {leak }}$ where $I_{\text {leak }}=V_{\text {clamp }} / R_{c}$ (where $R_{c}$ is cell resistance). Voltage- and time-dependent $\mathrm{Na}^{+}$and $\mathrm{K}^{+}$channels were blocked with TTX (10 $\mu \mathrm{M}$; Sigma) and $\mathrm{Cs}^{+}$, respectively. For measurement of $\mathrm{Ca}^{2+}$ currents, the composition of the internal solution was (in mM): CsCl 96, HEPES 20, EGTA $14, \mathrm{CaCl}_{2} 1$, $\mathrm{MgCl}_{2}$ 1, and ATP-Mg 5, titrated to $\mathrm{pH} 7.1$ with $\mathrm{CsOH}$; the external solution contained (in $\mathrm{mM}$ ): $\mathrm{CsCl} 135$, HEPES $10, \mathrm{CaCl}_{2}$ $10, \mathrm{MgCl}_{2} 1$, glucose 10 , and TTX $10 \mu \mathrm{M}$, titrated to $\mathrm{pH} 7.3$ with $\mathrm{CsOH}$. After penetration of a cell, a 5-min equilibration period allowed for dialysis of the cell interior with pipette solution.

In a separate set of experiments, $\mathrm{Ca}^{2+}$ current rundown was determined by recording currents during sequential depolarizations at 5 -min intervals. The first clamp was performed shortly after cell penetration $(t=0 \mathrm{~min})$. The mean current at each time point was calculated as a fraction of the initial peak current for each cell.

Time constant of dialysis. The interior of the cell was dialyzed with internal pipette solution via the open pipette tip, allowing control of intracellular ionic composition. Because experiments were performed with smaller pipette tip diameters than are commonly used $(13,26)$, the effectiveness of dialysis of the cell interior by internal pipette solution was determined. The rate of dialysis was studied by measuring changes in $\mathrm{Na}^{+}$current as intracellular $\mathrm{Na}^{+}$concentration came into equilibrium with the pipette solution. The decay of peak inward $\mathrm{Na}^{+}$current after cell penetration was measured with equal $\mathrm{Na}^{+}$concentration in the internal pipette and external solutions. The internal solution contained (in $\mathrm{mM}$ ): $\mathrm{NaCl} 60, \mathrm{CsCl} 45$, HEPES 20, EGTA 14 , $\mathrm{CaCl}_{2} 1, \mathrm{MgCl}_{2}$ 1, and ATP-Mg 5, titrated to $\mathrm{pH} 7.1$ with $\mathrm{CsOH}$. The external solution contained (in $\mathrm{mM}$ ): $\mathrm{NaCl} 60, \mathrm{CsCl} 75$, HEPES 10, $\mathrm{MgCl}_{2} 1, \mathrm{CaCl}_{2} 1$, and glucose 10 , titrated to $\mathrm{pH} 7.3$ with $\mathrm{CsOH}$. Repeated depolarizations (10 $\mathrm{ms}$ in duration) were performed at 1 -min intervals from a resting potential of $-80 \mathrm{mV}$ to a clamp potential of $0 \mathrm{mV}$. For each clamp step, the inward $\mathrm{Na}^{+}$current (normalized to the $\mathrm{Na}^{+}$current at 1 min after cell penetration) was measured. The decay time constants $\left(\tau_{\mathrm{Na}}\right)$ were calculated as the slope of the regression line of the logarithm of the mean $\mathrm{Na}^{+}$current versus time.

$\mathrm{Na}^{+}$current inhibition by TTX. To measure $\mathrm{Ca}^{2+}$ channel currents, TTX was included in the external solution to block $\mathrm{Ca}^{2+}$ influx through $\mathrm{Na}^{+}$channels. Cardiac $\mathrm{Na}^{+}$channels are known to be less sensitive to TTX than neuronal $\mathrm{Na}^{+}$channels $(23,24)$. Accordingly, the concentration of TTX required to block $\mathrm{Na}^{+}$current in isolated neonatal heart cells was determined. The peak $\mathrm{Na}^{+}$current was measured for depolarizations from a holding potential of $-80 \mathrm{mV}$ to a clamp potential of -20 $\mathrm{mV}$ in increasing concentrations of TTX. The internal solution contained (in $\mathrm{mM}$ ): $\mathrm{NaCl} \mathrm{10,} \mathrm{CsCl} 96$, HEPES 20, EGTA 14, $\mathrm{CaCl}_{2} 1, \mathrm{MgCl}_{2}$, and ATP-Mg 5, titrated to $\mathrm{pH} 7.1$ with CsOH. The external solution contained (in $\mathrm{mM}$ ): $\mathrm{NaCl} 40, \mathrm{CsCl} 95$, HEPES $10, \mathrm{MgCl}_{2} 1, \mathrm{CaCl}_{2} 1$, and glucose 10 , titrated to $\mathrm{pH} 7.3$ with $\mathrm{CsOH}$, to which various concentrations of TTX were added. For each of nine cells, the fractional response to TTX, $\left(\mathrm{I}_{0}-\right.$ $\left.I_{\text {peak }}\right) / I_{0}$, was calculated where $I_{0}$ was the peak $\mathrm{Na}^{+}$current in the absence of TTX. The apparent Km for TTX was then derived from Scatchard analysis of the mean fractional response for each concentration of TTX.

Statistical analysis. Measured values are reported as mean \pm SEM. The Km for TTX is reported with $95 \%$ confidence intervals because its distribution is non-Gaussian.

\section{RESULTS}

Whole cell data. In a total of 51 neonatal whole cell recordings, mean cell resistance measured $1.8 \pm 0.1 \mathrm{G} \Omega$ (ranging from 0.7 to $5.0 \mathrm{G} \Omega$ ) and pipette series resistance averaged $14 \pm 1 \mathrm{M} \Omega$. Cell surface area was $24.7 \pm 0.8 \times 10^{-6} \mathrm{~cm}^{2}$. This value agrees well with the $16 \times 10^{-6} \mathrm{~cm}^{2}$ calculated from planimetric data for 
the single cell in Figure 1, assuming a right cylinder $70 \mu \mathrm{m}$ long and $7 \mu \mathrm{m}$ wide.

Depolarization-induced action potentials in neonatal cells (Fig. 2) had a resting potential of $-71 \pm 2 \mathrm{mV}(n=11)$, an overshoot potential of $44 \pm 6 \mathrm{mV}(n=11)$, and an action potential amplitude of $115 \pm 2 \mathrm{mV}(n=11)$. The action potential duration was $620 \pm 100 \mathrm{~ms}(n=11)$. This value is significantly longer than that of $402 \pm 32 \mathrm{~ms}(n=9, p<0.001)$ found in neonatal papillary muscle (unpublished data from this laboratory) using the single sucrose gap preparation (4) or in a previous report using conventional microelectrodes (24). However, when the concentration of EGTA in the pipette was decreased to $0.04 \mathrm{mM}$ with no $\mathrm{Ca}^{2+}$ added to the internal solution, the action potential duration decreased to $397 \pm 14 \mathrm{~ms}(n=6, p<0.001$ versus isolated cells in $14 \mathrm{mM}$ EGTA). Thus, the action potential duration may be prolonged in isolated myocytes as a result of buffering of intracellular $\mathrm{Ca}^{2+}$ by EGTA.

$\mathrm{Ca}^{2+}$ currents. Depolarization of isolated neonatal cardiac myocytes in $10 \mathrm{mM} \mathrm{Ca}^{2+}$ solution induced time- and voltagedependent inward currents. Original records demonstrate typical inward $\mathrm{Ca}^{2+}$ currents that peak at 10 to $15 \mathrm{~ms}$ and are largely inactivated by the end of the 100-ms clamp step (Fig. 3).

The mean I-V relation of the peak current for 51 neonatal cells is shown in Figure 4. Significant activation of inward $\mathrm{Ca}^{2+}$ current occurs above $-30 \mathrm{mV}$. The membrane potential at which

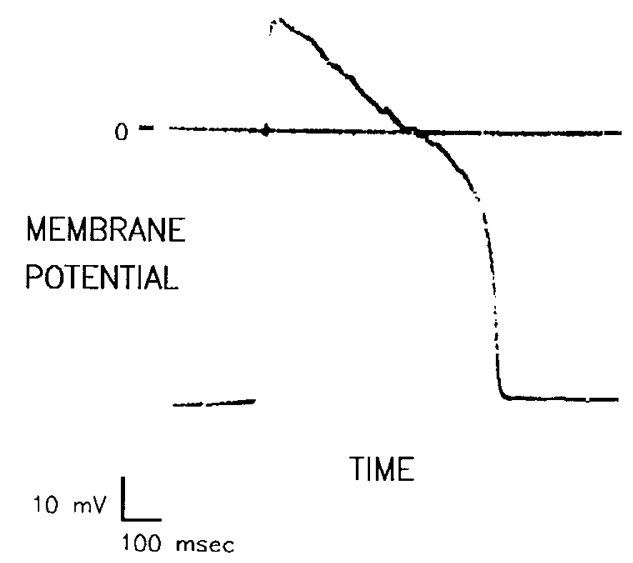

Fig. 2. Action potential measured from a cardiac myocyte isolated from a neonatal rabbit. Note the normal resting potential $(-75 \mathrm{mV})$, overshoot potential $(30 \mathrm{mV})$, and long action potential duration $(700$ $\mathrm{ms})$. All are indicators of the physiologic integrity of the isolated cell. The cell was bathed in Tyrode's solution containing $3.5 \mathrm{mM} \mathrm{Ca}^{2+}$. The internal electrode solution contained $120 \mathrm{mM} \mathrm{KCl}$.

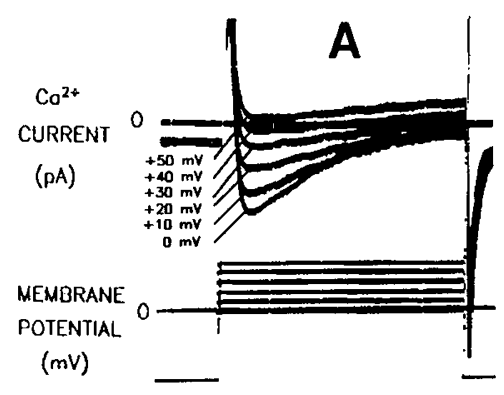

$$
\begin{aligned}
& 50 \mathrm{pA} \\
& 50 \mathrm{mV} \bigsqcup_{20 \mathrm{msec}}
\end{aligned}
$$

TIME the largest current occurred ranged from -10 to $30 \mathrm{mV}$ (mean $7.8 \pm 1.3 \mathrm{mV}$ ). The average value of these peak currents is 206 $\pm 10 \mathrm{pA}$. Of note, no second inward peak or hump in the I-V relation between membrane potentials of -30 to $0 \mathrm{mV}$ is seen. This region corresponds to the peak current of the T-type $\mathrm{Ca}^{2+}$ channels reported in preparations of mature myocytes (16).

Further, as shown in Figure 4, the depolarization-induced $\mathrm{Ca}^{2+}$ current is dependent on the external $\mathrm{Ca}^{2+}$ concentration. Decreasing external $\left[\mathrm{Ca}^{2+}\right]$ decreased the amplitude of the net current and shifts the I-V relation toward less positive values. Regression lines calculated to fit the linear portions of the ascending limb of the I-V relation curves have similar slopes and are separated by $26 \mathrm{mV}$. This value is comparable to the $29-\mathrm{mV}$ separation expected for a 10 -fold increase in concentration gradient predicted by the Goldman-Hodgkin-Katz equation.

A progressive "rundown" of $\mathrm{Ca}^{2+}$ current has been well described in chromaffin cells (28) and preparations of adult myocytes (29). Accordingly, serial recordings of voltage-gated $\mathrm{Ca}^{2+}$ currents were made (every $5 \mathrm{~min}$ ) in 49 cells. The mean peak inward current was found to decrease progressively, reaching an amplitude of approximately $50 \%$ of its initial value after $20 \mathrm{~min}$ (Fig. 5). This progressive, and apparently irreversible, fall in $\mathrm{Ca}^{2+}$ current may influence measures of maximal $\mathrm{Ca}^{2+}$ conductance. However, $90 \%$ of the current remained 5 min after the initial recordings. It therefore appears that allowing a 5 -min period for cell dialysis with pipette solution has only a small effect on measurements of peak inward $\mathrm{Ca}^{2+}$ current.

Rate of intracellular dialysis. The rate of dialysis of the cell interior was determined using the driving force for $\mathrm{Na}^{+}$current as a measure of intracellular $\mathrm{Na}^{+}$concentration. Voltage clamp steps to $0 \mathrm{mV}$ with equal internal and external $\mathrm{Na}^{+}$concentrations should produce no $\mathrm{Na}^{+}$current because the driving force for $\mathrm{Na}^{+}$movement across the cell membrane is zero. Therefore, after penetration of the cell with a pipette containing an $\mathrm{Na}^{+}$ concentration equal to the bath solution, the time course of the decay of inward $\mathrm{Na}^{+}$current during sequential voltage clamp steps provides an estimate of the time required for equilibration of pipette $\mathrm{Na}^{+}$with intracellular $\mathrm{Na}^{+}(28)$. In six neonatal cells, the time course of cell dialysis appeared to be a combination of an early rapid fall in $\mathrm{Na}^{+}$current $\left(\tau_{\mathrm{Na}}=1.2 \mathrm{~min}\right)$ and a slower, later decay $\left(\tau_{\mathrm{Na}}=2.6 \mathrm{~min}\right)$ (Fig. 6). The magnitude of the $\mathrm{Na}^{+}$ current at 5 min was $10 \%$ of the $\mathrm{Na}^{+}$current at 1 min. Thus, equilibration of low molecular weight solutes between the sarcoplasm and the pipette solution was largely accomplished within 5 min after penetration of the cell.

TTX sensitivity. To prevent $\mathrm{Ca}^{2+}$ influx through $\mathrm{Na}^{+}$channels $(15,16)$, TTX was added to the experimental solution. To determine the concentration of TTX needed to inhibit current

Fig. 3. Original records of the current response of a neonatal myocyte to a series of voltage steps. The panel on the left shows transsarcolemmal $\mathrm{Ca}^{2+}$ current (top) and cell membrane potential (bottom) as a function of time. Voltage clamp steps ranging from $0 \mathrm{mV}$ to $50 \mathrm{mV}$ are superimposed at the left $\left(\mathrm{V}_{\text {hold }}=-80 \mathrm{mV}\right)$. The panel on the right displays current and voltage traces from the same cell during voltage clamp steps ranging from $-40 \mathrm{mV}$ to $0 \mathrm{mV}$. Inward current is displayed as downward (negative) deflections. Zero current and potential lines are also displayed. After a brief capacitive spike, an inward current rapidly activates and then gradually inactivates over the course of a 100-ms voltage clamp. Cell no. 160 . 


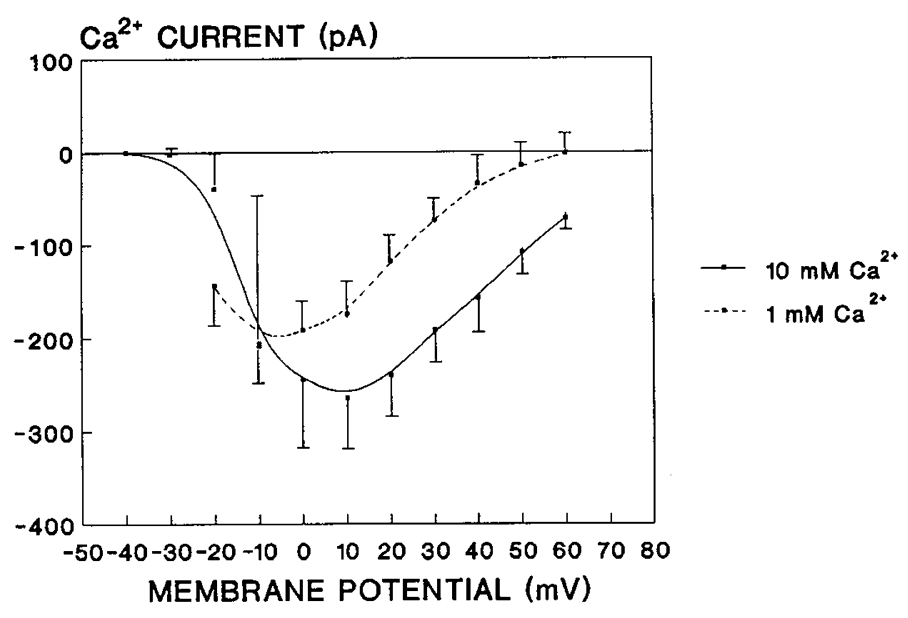

Fig. 4. Peak $\mathrm{Ca}^{2+} \mathrm{I}-\mathrm{V}$ relation and the effect of external $\left[\mathrm{Ca}^{2+}\right]$. In 10 $\mathrm{mM} \mathrm{Ca}{ }^{2+}$ external solution, $\mathrm{Ca}^{2+}$ channel activation occurs at clamp potentials greater than $-30 \mathrm{mV}\left(\mathrm{V}_{\text {hold }}=-80 \mathrm{mV}\right.$, values represent mean $\pm \mathrm{SEM}, n=8$, curves drawn by hand). Maximal inward current occurs at a clamp potential of $10 \mathrm{mV}$. The $\mathrm{Ca}^{2+} \mathrm{I}-\mathrm{V}$ relation in $1 \mathrm{mM} \mathrm{Ca}^{2+}(n$ $=7$ ) has a smaller peak amplitude, and the linear portion of the curve is shifted toward more negative potentials. This is consistent with the predicted behavior of a current carried mainly by $\mathrm{Ca}^{2+}$ ions (see text for further discussion).

\section{FRACTIONAL CURRENT}

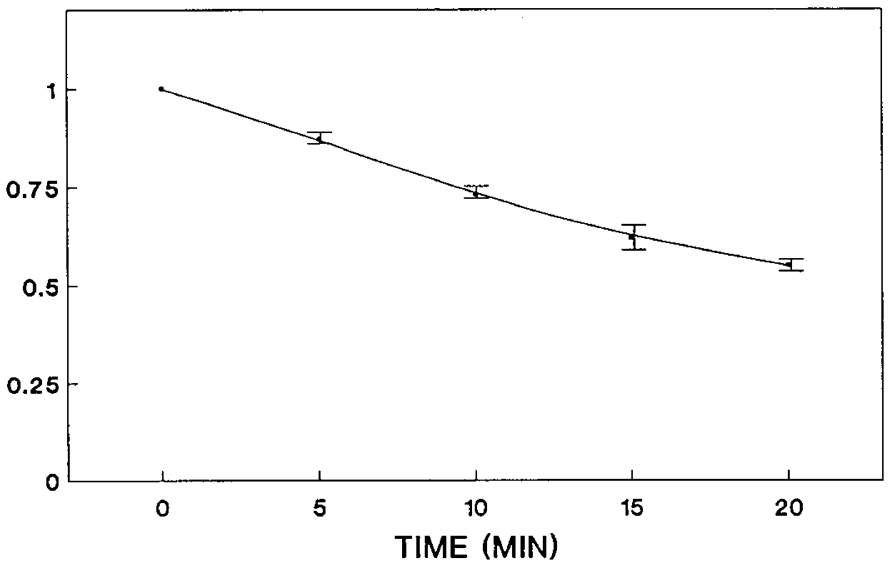

Fig. 5. $\mathrm{Ca}^{2+}$ current rundown. Depolarization-induced $\mathrm{Ca}^{2+}$ current (expressed as a fraction of the current at time $t=0 \mathrm{~min}$ ) is plotted as a function of time for repeated stimulations. Values are means \pm SEM of measurements from 16 to 49 cells. The curve is drawn by hand $\left(\mathrm{V}_{\text {hold }}=\right.$ $-80 \mathrm{mV}, \mathrm{V}_{\text {clamp }}=10 \mathrm{mV}$ ). The current decreased to $55 \%$ of its initial value in $20 \mathrm{~min}$.

flow through $\mathrm{Na}^{+}$channels in neonatal myocytes, the $\mathrm{Km}$ for TTX inhibition of $\mathrm{Na}^{+}$current was determined. TTX added to the external solution inhibited depolarization-induced $\mathrm{Na}^{+}$current $\left(\mathrm{V}_{\text {hold }}=-80 \mathrm{mV}, \mathrm{V}_{\text {clamp }}=-20 \mathrm{mV}\right)$ in a dose-dependent fashion (Fig. 7). TTX $(10 \mu \mathrm{M})$ inhibited $\mathrm{Na}^{+}$channel conductance by greater than $98 \%$. Using Scatchard analysis, the $\mathrm{Km}$ for inhibition was $0.37 \mu \mathrm{M}$ (95\% confidence limits $=0.26$ to 0.62 $\mu \mathrm{M}, n=9)$. This value is similar to that reported for $\mathrm{Na}^{+}$channel inhibition (concentration required for half-maximal response $=$ $0.94 \mu \mathrm{M})$ in intact fetal rat ventricle (23).

\section{DISCUSSION}

We have described the measurement of voltage-gated $\mathrm{Ca}^{2+}$ currents in acutely isolated myocytes from neonatal rabbit hearts. The whole-cell voltage clamp preparation for isolated myocytes has many advantages over multicellular preparations used in studying excitable cell membranes. It provides voltage clamp

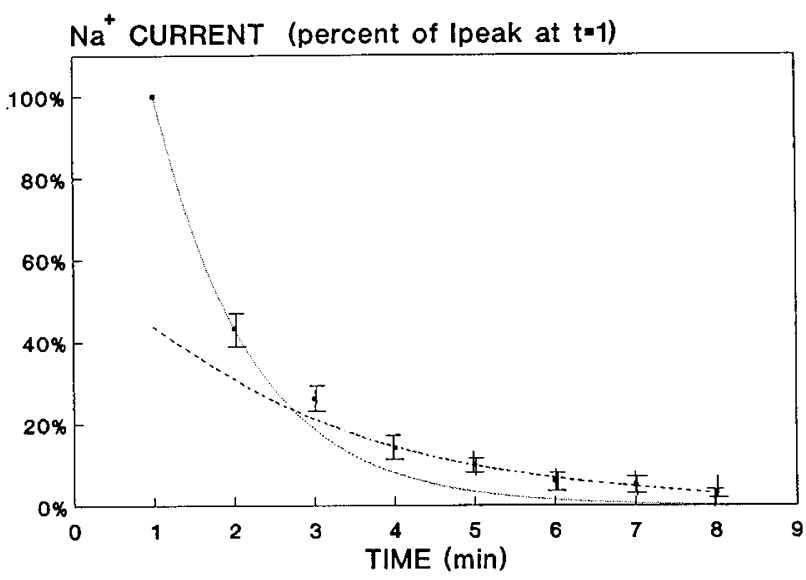

Fig. 6. Time course of cell dialysis. $\mathrm{Na}^{+}$current is used as an indication of dialysis of the cell interior with pipette solution. Depolarizationinduced inward $\mathrm{Na}^{+}$current (without TTX in the external solution) is plotted as a function of time (mean of six cells). This current decreases logarithmically as the transmembrane $\mathrm{Na}^{+}$concentration gradient decreases as a result of dialysis of the cell. The measurements are expressed as a percentage of the current at time $t=1 \mathrm{~min}$ after cell penetration. Internal and external solutions contained $60 \mathrm{mM} \mathrm{Na}^{+}$. $\mathrm{V}_{\text {hold }}=-80 \mathrm{mV}$ and $\mathrm{V}_{\text {clamp }}=0 \mathrm{mV}$. The $\tau_{\mathrm{Na}}$ for the initial component of dialysis (defined by the first two points, dotted line) is $1.2 \mathrm{~min}$, and that of the slower component (five points, dashed line) is $2.6 \mathrm{~min}$. See text for more detailed analysis.

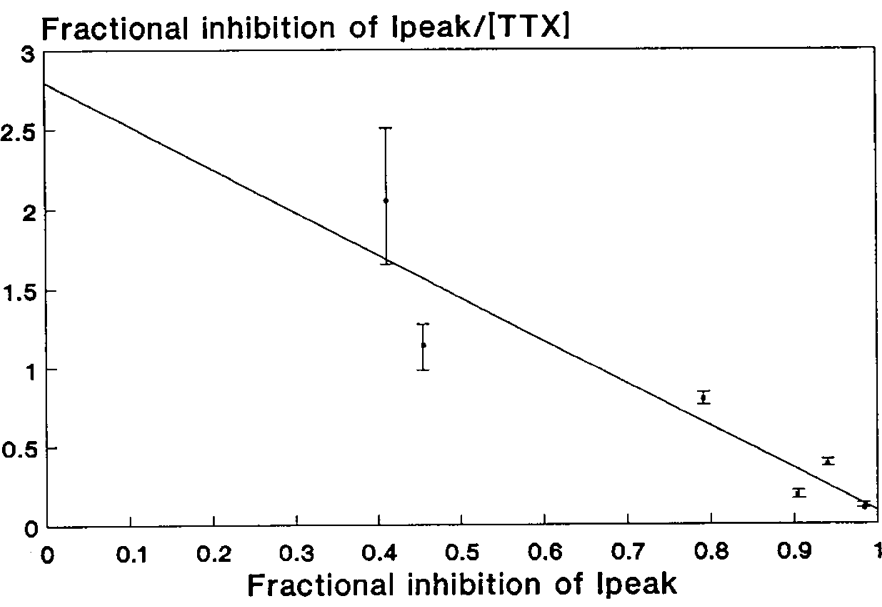

Fig. 7. Scatchard plot of the inhibition of peak $\mathrm{Na}^{+}$current by TTX Depolarization-induced inward $\mathrm{Na}^{+}$current was inhibited by the addition of 0.2 to $10 \mu \mathrm{M}$ TTX to the external solution $\left(\mathrm{V}_{\text {hold }}=-80 \mathrm{mV}, \mathrm{V}_{\text {clamp }}=\right.$ $-20 \mathrm{mV}$ ). Consistent with simple Michaelis-Menten kinetics, Scatchard analysis (fractional inhibition/[TTX] plotted vs fractional inhibition) of the dose-dependent inhibition of $\mathrm{Na}^{+}$current produces a linear plot. However, because of the scatter of the experimental points, more complex kinetic behavior cannot be excluded. Values represent means \pm SEM for two to six cells. The apparent $\mathrm{Km}(-1 /$ slope) for inhibition of $\mathrm{Na}^{+}$current by TTX in neonatal cells is $0.37 \mu \mathrm{M}(n=9)$. In $10 \mu \mathrm{M}$ TTX, greater than $98 \%$ of depolarization-induced $\mathrm{Na}^{+}$current is blocked. Voltage clamps performed in the absence of internal or external $\mathrm{Na}^{+}$or TTX occasionally demonstrated transient inward currents. These currents were blocked by $10 \mu \mathrm{M}$ TTX (data not shown) and may reflect movement of ions other than $\mathrm{Na}^{+}$through the $\mathrm{Na}^{+}$channel. Therefore, $10 \mu \mathrm{M}$ TTX was included in the external solution during all studies of $\mathrm{Ca}^{2+}$ currents.

control of the cell membrane and allows for direct measurement of transsarcolemmal currents. It also permits experimental control of the intracellular ionic environment of the cell. Furthermore, rapid changes in solutions bathing the exterior of the cell can be accomplished with only a minimal diffusion barrier. In 
contrast, in multicellular preparations, the interstitial space has been shown to allow large localized concentration gradients. Our results suggest that the whole-cell voltage clamp technique may be used to explore developmental differences in cardiac $\mathrm{Ca}^{2+}$ current.

Isolated cell characteristics. Isolated neonatal rabbit myocytes retain many characteristics of intact viable cardiac cells including cell morphology, gross cellular ultrastructure, the exclusion of trypan blue, and the ability to remain stable without spontaneous contractions in high $\mathrm{Ca}^{2+}$ medium. Moreover, they develop action potentials and contract in response to depolarizing currents (25).

The morphology of action potentials recorded from isolated cells (Fig. 2) is similar to that recorded in isolated papillary muscles $(4,24)$, and the action potential amplitude is virtually identical (24). The effects of changes in external $\mathrm{K}^{+}$on resting membrane potential in newborn rabbit papillary muscle has been previously measured at two concentrations (24). Recently, we have described the $\mathrm{K}^{+}$-dependence of resting membrane potential of isolated neonatal myocytes and its relation to inwardly rectifying $\mathrm{K}^{+}$channels with comparable results (30).

The action potential duration of isolated myocytes was $620 \pm$ $100 \mathrm{~ms}$ when the cell was dialyzed with solution containing 14 mM EGTA plus $1 \mathrm{mM} \mathrm{CaCl}$. However, in low EGTA internal solution ( $40 \mu \mathrm{M}$ EGTA with no added $\mathrm{Ca}^{2+}$ ), the action potential duration was not significantly different from that recorded in isolated papillary muscles in the single sucrose gap apparatus. The increased action potential duration with high EGTA pipette solution may indicate the presence of a $\mathrm{Ca}^{2+}$-dependent repolarizing current (perhaps carried by a $\mathrm{Ca}^{2+}$-dependent $\mathrm{K}^{+}$channel) in neonatal cardiac myocytes. The presence of a long action potential duration has been considered an "important indication of the robustness of the cell, and this is required for recording the very slow inward current" (30). These results suggest that isolated myocytes retain the electrophysiological properties of native ventricular tissue.

$\mathrm{Ca}^{2+}$ currents. A depolarization-induced time- and voltagedependent inward $\mathrm{Ca}^{2+}$ current was measured in neonatal myocytes. The mean current voltage relation exhibited channel activation at potentials positive to $-30 \mathrm{mV}$ and maximal inward current near $10 \mathrm{mV}$. Experimental conditions were adjusted to insure that measured currents were carried exclusively by $\mathrm{Ca}^{2+}$ ions. To provide additional evidence that the measured current resulted from the movement of $\mathrm{Ca}^{2+}$, the effect of changes in external $\mathrm{Ca}^{2+}$ concentration was determined. The results shown in Figure 4 demonstrate that the magnitude of the inward current is dependent on external $\mathrm{Ca}^{2+}$ concentration. As predicted by the Goldman-Hodgkin-Katz equation, the I-V relation is shifted toward more negative values when external $\mathrm{Ca}^{2+}$ is decreased. As a result of buffering by EGTA, $\mathrm{Ca}^{2+}$ concentration in the cell is very low (less than $0.1 \mu \mathrm{M}$ ) and $\mathrm{Ca}^{2+}$ current does not become outward even at very positive potentials.

To exclude $\mathrm{Ca}^{2+}$ movement via $\mathrm{Na}^{+}$and $\mathrm{K}^{+}$channels, these channels were blocked with TTX and $\mathrm{Cs}^{+}$, respectively. TTX $(10 \mu \mathrm{M})$ was shown to decrease inward current through $\mathrm{Na}^{+}$ channels by $98 \%$. $\mathrm{Na}^{+}$channel blockade is crucial in studies of voltage-gated $\mathrm{Ca}^{2+}$ channels because T-type $\mathrm{Ca}^{2+}$ channels exhibit time and voltage dependence very similar to that of $\mathrm{Na}^{+}$ channels. However, the Scatchard analysis shown in Figure 7 suggests that in the presence of $10 \mu \mathrm{M}$ TTX, the measured current is almost certainly carried by $\mathrm{Ca}^{2+}$ ions passing through $\mathrm{Ca}^{2+}$ selective channels.

The $\mathrm{Ca}^{2+}$ current measured in these experiments exhibited a time and voltage dependence similar to that reported for L-type $\mathrm{Ca}^{2+}$ channels in adult myocardium. However, the magnitude of the peak current $(210 \mathrm{pA})$ was much smaller than previously reported for preparations of adult myocytes from other species $(1-2 \mathrm{nA})(15,29)$. In addition, the I-V relation did not show the characteristic second hump corresponding to the activation of
T-type $\mathrm{Ca}^{2+}$ channels found in adult myocytes at relatively negative membrane potentials (16).

Other technical considerations. Because of the smaller size of neonatal myocytes, higher resistance microelectrodes were used in our experiments as compared with those used in single-cell studies of isolated adult myocytes. Despite the fact that the reduced tip diameter of these electrodes resulted in an increased series resistance, series resistance compensation was not necessary. Because of the small magnitude of the measured currents, the maximum potential drop across the cell access resistance (14 $\mathrm{M} \Omega \times 200 \mathrm{pA}=2.8 \mathrm{mV}$ ) was within acceptable limits (30).

The rate of dialysis of the cell interior by internal pipette solution was also affected by the smaller pipette size. The rate of dialysis is an important factor in studies using the whole-cell voltage clamp technique, which takes advantage of dialysis of the cell to control the intracellular environment. When the decay of the inward $\mathrm{Na}^{+}$current was used as an indicator of the rate of equilibration of the sarcoplasm with internal pipette solution (Fig. 6), the decay displayed an exponential time course with two time constants (initial $\tau_{\mathrm{Na}}=1.2 \mathrm{~min}$, final $\tau_{\mathrm{Na}}=2.6 \mathrm{~min}$ ). These values are substantially longer than that reported for chromaffin cells $(0.1 \mathrm{~min})$ using larger, 1 - to $3-\mathrm{M} \Omega$ pipettes $(26)$. The relationship between diffusional rates, pipette and cell size, and the molecular weight of the diffusing substance has been recently described by Pusch and Neher (27). Using the initial dialysis time constant $\left(\tau_{\mathrm{Na}}\right)$ and the measured pipette series resistance, the calculated normalized diffusional rate for $\mathrm{Na}^{+}$from our experiments, $\mathrm{k}_{\mathrm{Na}} \times \mathrm{C}_{\mathrm{m}}{ }^{1.5}$ (where $\mathrm{k}_{\mathrm{Na}}=\mathrm{R}_{\mathrm{s}} / \tau_{\mathrm{Na}}$ and $\mathrm{C}_{\mathrm{m}}$ is cell membrane capacitance), is $1340 \times 10^{-14} \Omega \times \mathrm{F}^{1.5} \times \mathrm{s}^{-1}$, which is similar to $1966 \pm 831 \times 10^{-14} \Omega \times F^{1.5} \times \mathrm{s}^{-1}$ measured by Pusch and Neher (27). Similarly, using equation 18 from their article,

$$
\tau(\mathrm{s})=\left(\mathrm{V} / \mathrm{V}_{0}\right) \times(0.6 \pm 0.17) \times \mathrm{R}_{\mathrm{s}} \times(\text { molecular } \mathrm{wt})^{1 / 3}
$$

where $\mathrm{V}$ is the cell volume $\left(2700 \mu \mathrm{m}^{3}\right.$ for a cylinder $7 \times 7 \times 70$ $\mu \mathrm{m})$ and $\mathrm{V}_{0}=1897 \mu \mathrm{m}^{3}$, time constants of $0.6,0.7$, and $1.5 \mathrm{~min}$ are calculated for $\mathrm{Na}^{+}, \mathrm{Ca}^{2+}$, and EGTA, respectively. The calculated time constant for $\mathrm{Na}^{+}$is similar to the $\tau_{\mathrm{Na}}$ that we measured for $\mathrm{Na}^{+}$dialysis. These values compare favorably with those estimated for larger adult myocytes $(20 \times 26 \times 150 \mu \mathrm{m}$, see reference 7). Cells of this size have a volume approximately 20 times that of neonates and, thus, similarly rapid dialysis requires very low resistance pipettes $\left(\mathrm{R}_{\mathrm{s}}\right.$ less than $\left.1 \mathrm{M} \Omega\right)$.

In our experiments, cells were allowed to equilibrate for a minimum of $5 \mathrm{~min}$ after cell penetration before the start of data collection. Of note, however, no transient component of $\mathrm{Ca}^{2+}$ current rundown with a time constant similar to that expected for cell dialysis is seen (Fig. 5). Thus, sufficient dialysis occurs within the first few minutes after cell penetration to avoid major artifactual effects on measured $\mathrm{Ca}^{2+}$ currents.

\section{CONCLUSIONS}

The results of our investigation suggest that neonatal rabbit myocytes may be isolated by enzymatic dissociation and that they demonstrate time- and voltage-dependent inward $\mathrm{Ca}^{2+}$ currents similar to those described for L-type $\mathrm{Ca}^{2+}$ channels in preparations of mature myocytes. However, these currents are much smaller than those reported for adult cells, perhaps in part because of the smaller size of the neonatal cells. Additionally, Ttype $\mathrm{Ca}^{2+}$ currents are not readily apparent in these immature cells and may emerge in an age-related fashion. The application of the whole-cell voltage clamp technique to acutely isolated rabbit cells provides a more complete description of voltagegated $\mathrm{Ca}^{2+}$ channels than has previously been possible in immature mammalian cardiac tissue and allows for direct comparison of membrane $\mathrm{Ca}^{2+}$ currents between neonatal and adult myocytes using similar isolation techniques.

Acknowledgments. The authors thank Mathilde Mazlonmian for her assistance in the isolation of neonatal myocytes and Sarah 
Warren for her help in the preparation of this manuscript. We would also like to thank James Weiss, Scott Lamp, and Sen Ji of the UCLA "Heart Lab" for their suggestions regarding the whole-cell voltage clamp technique.

\section{REFERENCES}

1. Chapman RA 1983 Control of cardiac contractility at the cellular level. Am J Physiol 245:H535-H552

2. Langer GA 1986 Calcium at the sarcolemma: its role in control of myocardial contraction. In: Nathan RD (ed) Cardiac Muscle: The Regulation of Excitation and Contraction. Academic Press, Orlando, FL, pp 269-281

3. Jarmakani JM, Nakanishi T, George BL, Bers D 1982 Effect of extracellula calcium on myocardial mechanical function in the neonatal rabbit. Dev Pharmacol Ther 5:1-13

4. Klitzner T, Friedman WF 1988 Excitation-contraction coupling in developing mammalian myocardium: evidence from voltage clamp studies. Pediatr Res $23: 428-432$

5. Maylie JG 1982 Excitation-contraction coupling in neonatal and adult myocardium of cat. Am J Physiol 284:H834-H843

6. Morad M, Cleemann L 1987 Role of $\mathrm{Ca}^{2+}$ channel in development of tension in heart muscle. J Mol Cell Cardiol 19:527-553

7. Nassar R, Reedy MC, Anderson PAW 1987 Developmental changes in the ultrastructure and sarcomere shortening of the isolated rabbit ventricular myocyte. Circ Res 61:465-483

8. Page E, Buecker JL 1981 Development of dyadic junctional complexes between sarcoplasmic reticulum and plasmalemma in rabbit left ventricular myocardial cells: morphometric analysis. Circ Res 48:519-522

9. Sheldon CA, Friedman WF, Sybers HD 1976 Scanning electron microscopy of fetal and neonatal lamb cardiac cells. J Mol Cell Cardiol 8:853-862

10. Fabiato A, Fabiato F 1978 Calcium-induced release of calcium from the sarcoplasmic reticulum of skinned cells from adult human, dog, cat, rabbit rat, and frog hearts and from fetal and newborn rat ventricles. Ann NY Acad Sci 307:491-522

11. Mahony L, Jones LR 1986 Developmental changes in cardiac sarcoplasmic reticulum in sheep. $\mathrm{J}$ Biol Chem 261:15257-15265

12. Nayler WG, Fassold E 1977 Calcium accumulating and ATPase activity of cardiac sarcoplasmic reticulum before and after birth. Cardiovasc Res 11:231-237

13. Hamill OP, Neher ME, Sakmann B, Sigworth FJ 1981 Improved patch-clamp techniques for high-resolution current recording from cells and cell-free membrane patches. Pflugers Arch 391:85-100

14. Pelzer D, Trautwein W 1987 Currents through ionic channels in multicellular cardiac tissue and single heart cells. Experientia 43:1153-1162

15. Lee KS, Tsien RW 1982 Reversal of current through calcium channels in dialyzed single heart cells. Nature 297:498-501

16. Mitra R, Morad M 1986 Two types of calcium channels in guinea pig ventricular myocytes. Proc Natl Acad Sci USA 63:5340-5344

17. Bean BP, Nowycky MC, Tsien RW $1984 \beta$-Adrenergic modulation of calcium channels in frog ventricular heart cells. Nature 307:371-375

18. Bkaily G, Peyrow M, Yamamoto $T$, Sculptoreanu A, Jacques D, Sperelakis $N$ 1988 Macroscopic $\mathrm{Ca}^{2+} \mathrm{Na}^{+}$and $\mathrm{K}^{+}$currents in single heart and aortic cells. Mol Cell Biochem 80:59-72

19. Cohen NM, Lederer WJ 1987 Calcium current in isolated neonatal rat ventricular myocytes. J Physiol (Lond) 391:169-191

20. Gurney AM, Nerbonne JM, Lester HA 1985 Photoinduced removal of nifedipine reveals mechanisms of calcium antagonist action on single heart cells. J Gen Physioi 86:353-379

21. Reuter H, Stevens CF, Tsien RW, Yellen G 1982 Properties of single calcium channels in cardiac cell culture. Nature 297:501-504

22. Osaka T, Joyner RW 1991 Developmental changes in calcium currents in rabbit ventricular cells. Circ Res 68:788-796

23. Nathan RD 1981 Aggregates of fetal rat heart cells: electrophysiology and tetrodotoxin sensitivity. J Mol Cell Cardiol 13:241-249

24. Osaka T, Ramza BM. Tan RC, Joyner RW 1989 Developmental changes in the electrophysiologic properties of rabbit papillary muscles. Pediatr Res 26:543-547

25. Chin TK, Friedman WF, Klitzner TS 1990 Developmental changes in cardiac myocyte calcium regulation. Circ Res 67:574-579

26. Marty A, Neher E 1983 Tight-seal whole-cell recording. In: Sakmann B, Neher E (eds) Single-Channel Recording. Plenum Press, New York, pp 107-122

27. Pusch M Neher E 1988 Rates of diffusional exchange between small cells and a measuring patch pipette. Pflugers Arch 411:204-211

28. Fenwick EM, Marty A, Neher E 1982 Sodium and calcium channels in bovine chromaffin cells. J Physiol (Lond) 331:599-635

29. Belles B, Malecot CO, Hescheler J, Trautwein W 1988 Rundown of the $\mathrm{Ca}^{2+}$ current during long whole-cell recordings in guinea pig heart cells: role of phosphorylation and intracellular calcium. Pflugers Arch 411:353-360

30. Chen F, Wetzel GT, Friedman WF, Klitzner TS 1991 Single-channel recording of inwardly rectifying potassium currents in developing myocardium. J Mol Cell Cardiol (in press)

31. Lee KS, Noble D, Lee E, Spindler AJ 1984 A new calcium current underlying the plateau of the cardiac action potential. Proc R Soc Lond [Biol] 223:3548 